\title{
The Effect of Return on Assets and Return on Equity to the Stock Price
}

\author{
Fitri Sukmawati \\ Department of Accounting \\ Universitas Widyatama \\ Bandung, Indonesia \\ fitri.sukmawati@widyatama.ac.id
}

\author{
Innes Garsela \\ Department of Accounting \\ Universitas Informatika dan Bisnis Indonesia \\ Bandung, Indonesia
}

\begin{abstract}
This study aims to determine how the "Effect of return on assets and return on equity to the stock price on PT.Indocement Tunggal Prakarsa Tbk". This study uses descriptive-quantitative analysis using classical assumption test. Collecting data using secondary data in the financial statements. The statistical technique used is multiple linear regression analysis, multiple correlation, determination, $t$ test and $f$. Results of reseach variation return on Asset at PT Indocement Tbk. able to explain the variation on stock prices, while ROA increases, stock prices also tend to rise, Variation Return On Equity in PT Indocement Tbk. Vaariasi able to explain the stock price, which when ROE increases, the resulting share price decline. Variations ROA and ROE are jointly able to explain the variation on share prices.
\end{abstract}

Keywords : Return On Assets (ROA), Return On Equity (ROE) and stock price

\section{INTRODUCTION}

The higher the level of ROA and ROE, the higher the level of income derived by shareholders in PT.Indocement Tunggal Tbk. Below is presented data on the level of ROA, ROE and Shares in PT.Indocement Tunggal Tbk 2009-2013.

TABLE 1

Data ROA, ROE and Shares PT.Indocement Tunggal Tbk

\begin{tabular}{|c|c|c|c|}
\hline TAHUN & ROA (\%) & ROE (\%) & SAHAM \\
\hline 2009 & 28.59 & 35.54 & 13.700 \\
\hline 2010 & 21.01 & 24.66 & 15.950 \\
\hline 2011 & 19.84 & 22.89 & 17.050 \\
\hline 2012 & 20.93 & 24.53 & 22.450 \\
\hline 2013 & 18.84 & 21.81 & 20.000 \\
\hline
\end{tabular}

Source: Data Bursa Efek Indonesia (BEI)

According to Table 1.1 presents the share price development, ROA and ROE at PT.Indocement Tunggal Tbk for five years. In 2009 to 2011 ROA decreased by $12.26 \%$ and ROE decreased by $12.1 \%$, but its share price rose during the year. In 2012 ROA increased by $1.09 \%$ and ROE increased by $1.64 \%$ and its stock price also rose. In 2013 ROA decreased return of $2.09 \%$ and ROE decreased by $2.72 \%$, while its share price decline. this can be a problem for the company because of ROA and ROE were unstable that affect stock prices.
It can be seen stock prices PT.Indocement Tunggal Tbk, change every year for the respective period of 2009 to 2013. Based on these data can be presumed that the rise and fall of stock prices affected by how investors in recognition of the company's shares on views on the development of the company. If the rate of development of the company deteriorates or frequent losses that investors will buy the shares at a cheap price or lower, and vice versa if the pace of development of the company's progress with good results then the investor will purchase shares at a price too high.

This shows the stock price at PT.Indocement Tunggal Tbk fluctuate. Therefore, changes in the stock becomes important to be noticed by the actors in the stock market or the capital of both the issuer and the market price of the stock formed from the forces of demand and supply in the capital market. [1] In this research, there will be explanation about the effect of Price to Book Value (PBV), Dividend Payout Ratio (DPR), Return on Equity (ROE), Return on Asset (ROA), and Earning per Share (EPS) toward issuers included in LQ 45 Index. Based on explanation above, financial ratio such as Price to Book Value (PBV), Dividend Payout Ratio (DPR), and Earning per Share (EPS) should be considered by investors who want to invest their money in stocks. [2] Profitability gap analyzis shows that milk processors achieved significantly higher profitability compared to cow breeders. Furthermore research results suggest that the existence of differences in the level of profitability among the participants in the milk production primarily affects capital turnover, and then the profit margin. [3] recommended that firm size, leverage, profitability and firm growth should be enhanced in view of their influence in increasing the share price. [4] The results from correlation analysis show that there is no significant relationship between managerial ownership and risk-taking and firm performance. [5] that Return On Equity, Sales Growth and Return On Assets simultaneously affect the dividend policy

Referring to the above problems, the authors intend to analyze and examine the issue and take the title of " TheEffect Return On Asset (ROA) and Return On Equity (ROE) on stock price on PT.Indocemment Tunggal Tbk, Listed in Indonesia Stock Exchange (BEI) Period 2008-2014 ". 
Based on the above background, the identification of issues that will be discussed in this study are How much influence the ROA and ROE to the stock price.

the research objectives to be achieved in this research is to determine how much influence ROA and ROE on stock price.

\section{LITERATURE REVIEW}

The company's performance can be demonstrated in the company's reports useful for decision makers for investors who will invest their funds in the stock market. In the capital market, securities are often traded shares. Shares are securities as proof of ownership or possession of individuals and intuition issued by a company formed limited liability companies. Shares stated that the owner of these shares are part of the company owners as well. Thus when an investor buys a stock, he became the owner or a part of the company's shareholders. the stock price is the division between corporate capital and number of shares in issue. between

There are several factors that affect the stock price,

Other: Return On Assets (ROA) and Return On Equity (ROE). While the relationship between these variables are as follows:

According to Syamsuddin ROA also be an indicator that a company can use its financial resources to generate value for shareholders. The greater the ROA of a company meal, the better the company's financial performance. High ROA is also attracting investors to invest because it is companies are able to leverage their assets to the business. [6] ROA can be determined by the following formula:.

$$
\mathrm{ROA}=\frac{\text { Earning After Tax }}{\text { Total Assets }} \times 100 \%
$$

The traditional perspective of the agency theory stresses that larger boards can reduce potential shareholder-management conflicts because of the increased vigilance to oversee management's actions [7]. In addition, added that the resource dependence theory perspective places greater premium on large boards because of greater links and access to resources. Using data from Australian companies, they found a positive correlation between board size and Tobin's q, a market-based measure of firm performance; however, no significant relationship was exhibited when Return on Assets (ROA), an accounting-based measure of performance, was used.

According to Syamsuddin Return On Equity (ROE) is the ratio used to measure the ability of its own capital to generate benefits for all shareholders, both common stock and preferred stock. This ratio is used by investors to see how far the company can provide benefits in the future. Return on equity is one measure of earnings (income) available for owners of firms (both common shareholders and preferred shareholders) on the capital that they invested in the company.

[8]Return on equity (ROE) is a closely watched financial ratio among equity investors. It is a strong measure of how well the management of a firm creates value for its shareholders.
The formula for calculating the ROE as follows:

$$
\mathrm{ROE}=\frac{\text { Earning After Tax }}{\text { equity }} \quad \times 100 \%
$$

Some research on the Effect Return On Assets (ROA) and Return On Equity (ROE) on stock price has a lot to do in Indonesia with a different approach, with different results. These differences may occur because of differences in every capital market conditions and the environment, differences in perceptions of researchers, as well as the data used is as follows: [9], Administration, University of Brawijaya with the title of the study, Effects of Debt To Equity Ratio, Return on Equity, Earnings Per Share and Price Earning Ratio On The Stock Market stating that the variable DER, ROE, EPS and PER simultaneously have significant influence on prices stock company food and beverages period 2008-2011. ROE partially influence on stock prices with sig. 0,001 and ROE major influence on stock prices was $86.2 \%$. Variable EPS partially influence on stock prices with sig. 0,003 and the influence of EPS on stock prices was $43.4 \%$. Variable PER partially no effect on stock prices because it has a sig. amounted to 0.111 , while the influence of PER on stock prices was $17.3 \%$.

ROE has the most dominant influence on stock prices of food and beverages period 2008-2011. This is reflected in the value of standardized beta coefficients which indicate that the value of the highest ROE among other independent variables, which amounted to $86.2 \%$. Results of research [10], stating that Based on the results of testing the first hypothesis can be seen that the Earning Per Share, Return on Assets, Net Profit Margin, Debt to Assets Ratio and Long Term Debt to Equity Ratio influence significantly influence stock prices Trading company listed in Indonesia stock Exchange 2010-2012 period with the level of influence (Adjusted R Square) together amounting to $69.6 \%$. Other variables such as Return On Assets, Net Profit Margin and Debt to Assets Ratio not significant effect on the stock price at Trade company listed in Indonesia Stock Exchange 2010-2012. Based on these results, the EPS is a variable that very need to be considered by the parties concerned because they affect the stock price.

[11] This study indicated that the relationship between the share price of listed companies and cash dividend payment. Most of the companies distribute dividend in shape of stock dividend. The study also showed that is significant change in the market price of share before and after the dividend declaration and payment is taken place.

[12] During the period 2007 to 2011, the results show that both logistic regression and discriminant analysis can predict financial distress, and that Return on Equity (ROE) and Return on Assets (ROA) are the most important two financial ratios, which help in predicting the financial distress of public companies listed in Amman stock Exchange. [13] despite on liberalization level on electricity market in these countries the effective management of return ratio, controlling the value and quality of company's debt and planning company's profitability on electricity market help to influence market share price. 


\section{METHODOLOGY}

Factory PT. Indocement is located in Coventry, West Java Cibinong on a land of 200 hectares. The factory premises within $45 \mathrm{Km}$ south of Jakarta and is located not far from the freeway or toll jagorawi. The factory premises selected for consideration by the mills nearby quarry limestone, clay and silica sand which is a key raw material in the cement industry. 3.1 Data Analysis Techniques

After the data measurement process is complete, the next stage should be done is the analysis phase, the research data analysis techniques using quantitative data by using statistical analysis using SPSS for Windows version 20.00.

Tests have been selected based on the purpose of the study, the number of variaber studied and the measurement scale used. Secondary data is data obtained in the form of readymade, have been collected and processed for the other party. Based on the description above, researchers selected statistical tests that will be performed include:

1. Multiple Linear Regression Analysis

Technical analysis of the data used in this study is the technique of multiple regression or multiple regression, to test the effect of ROA and ROE to the stock price. Multiple regression model is a regression analysis that explains the relationship between the dependent variable and several independent variables. Multiple regression equations were formulated as follows:

$$
\text { HSit }=\alpha+\beta \text { iROAit }+\beta 2 \text { ROEit }
$$

Where :

Hsit $=$ stock price of firm $\mathrm{i}$ in period $\mathrm{t}$

$\alpha=$ Coefficient constant

ROAit $=$ ROA of firm $\mathrm{i}$ in period $\mathrm{t}$

ROEit $=$ ROE $\mathrm{i}$ period $\mathrm{t}$

$1,2,3=$ coefficient of independent variable

Analysis of Multiple Correlation, This analysis is used to determine the relationship between two or more independent variables $(\mathrm{X} 1, \mathrm{X} 2, \ldots \mathrm{Xn})$ to the dependent variable (Y) simultaneously. This coefficient shows how much the relationship between the independent variables $(\mathrm{X} 1, \mathrm{X} 2, \ldots \ldots$ $\mathrm{Xn}$ ) simultaneously to the dependent variable (Y). $\mathrm{R}$ value ranges from 0 to 1 , the value of 1 means the closer the relationship is getting stronger, otherwise the value 0 , the closer the relationship is getting weaker.

Determination Analysis, Analysis of determination in multiple linear regression is used to determine the percentage contribution of the influence of the independent variables (X1, $\mathrm{X} 2, \ldots . . \mathrm{Xn}$ ) simultaneously to the dependent variable (Y). This coefficient indicates the percentage of variation of the independent variables used in the model is able to explain the variation of the dependent variable. $\mathrm{R} 2$ is equal to 0 , then there is no iota of influence given percentage contribution of independent variables on the dependent variable, or a variation of the independent variables used in the model does not explain the slightest variations in the dependent variable. Instead R2 is equal to 1 , then the percentage contribution of influence given by the independent variable on the dependent variable was perfect, or variations of the independent variables used in the model explains $100 \%$ variation of the dependent variable.

Test-F Test

The research hypotheses:

Ho $=$ ROA and ROE are not positive and significant effect on stock prices.

$\mathrm{Ha}=\mathrm{ROA}$ and ROE positive and significant effect on stock prices.

\section{RESULTS AND DISCUSSION}

\subsection{Development of ROA at PT.Indocement Tunggal Tbk}

Profitability is the company's ability to generate optimal profit. The ratio used is ROA, this ratio shows the ability of management to manage the assets to generate profits for the company. To know the development of Return on Assets in PT.Indocement Tunggal Tbk, the period 2008-2014 can be seen from the following table:

TABLE 2

Developments Return On Asset on PT.Indocement Tunggal Tbk period 2008-2014

\begin{tabular}{|l|c|c|c|}
\hline \multicolumn{1}{|c|}{ Year } & Net Profit & Total Assets & ROA \\
\hline 2008 & 1.745 .500 & 11.286 .706 & $15,47 \%$ \\
\hline 2009 & 2.746 .654 & 13.276 .270 & $20,69 \%$ \\
\hline 2010 & 3.224 .914 & 15.346 .145 & $21,01 \%$ \\
\hline 2011 & 3.596 .918 & 18.151 .331 & $19,82 \%$ \\
\hline 2012 & 4.760 .382 & 22.750 .160 & $20,92 \%$ \\
\hline 2013 & 5.012 .294 & 26.607 .241 & $18,84 \%$ \\
\hline 2014 & 5.274 .009 & 28.884 .973 & $18,26 \%$ \\
\hline
\end{tabular}

Source: Financial Statements PT.Indocement Tunggal Tbk

\subsection{Development of ROE in PT.Indocement Tunggal Tbk}

Profitability is the company's ability to generate optimal profit. The ratio used is ROE, this ratio shows the ability of management to manage equity to generate profits for the company. To know the development of Return On Equity in PT.Indocement Tunggal Tbk, the period 2008-2014 can be seen from the following table:

TABLE 3

Return On Equity Developments in PT.Indocement Tunggal Tbk period 2008-2014

\begin{tabular}{|c|c|c|c|}
\hline Year & Net Profit & Equity & ROE \\
\hline 2008 & 1.745 .500 & 8.500 .193 & $20,53 \%$ \\
\hline 2009 & 2.746 .654 & 10.680 .725 & $25,72 \%$ \\
\hline 2010 & 3.224 .914 & 13.007 .390 & $24,66 \%$ \\
\hline 2011 & 3.596 .918 & 15.733 .951 & $22,86 \%$ \\
\hline 2012 & 4.760 .382 & 19.418 .738 & $24,51 \%$ \\
\hline 2013 & 5.012 .294 & 22.977 .687 & $21,81 \%$ \\
\hline 2014 & 5.274 .009 & 24.784 .801 & $21,28 \%$ \\
\hline
\end{tabular}

Source: Financial Statements PT.Indocement Tunggal Tbk

4.3 Development of Stock Price PT.Indocement Tunggal 
The share price is the basic price of a stock that is used in the calculation of stock price index and the price is formed by the interaction between sellers and buyers of shares are motivated by their expectations of the benefits to be gained. To determine the share price development in PT.Indocement Tunggal Tbk, the period 2008-2014 can be seen from the following table:

TABLE 4

Stock Price Developments

on PT.Indocement Tunggal Tbk period 2008-2014

\begin{tabular}{|c|c|}
\hline Year & Stock Price \\
\hline 2008 & 4.600 \\
\hline 2009 & 13.700 \\
\hline 2010 & 15.950 \\
\hline 2011 & 17.050 \\
\hline 2012 & 22.650 \\
\hline 2013 & 20.000 \\
\hline 2014 & 25.000 \\
\hline
\end{tabular}

Source: Financial Statements PT.Indocement Tunggal Tbk

\subsubsection{Multiple Linear Regression Analysis}

Technical analysis of the data used in this study is the technique of multiple regression or multiple regression, to test the effect of ROA (X1) and ROE (X2) on stock prices (Y). Multiple regression model is a regression analysis that explains the relationship between the dependent variable and several independent variables. Multiple regression equations were formulated as follows:

TABLE 5

Multiple Linear Regression Analysis

Coefficients $^{\mathrm{a}}$

\begin{tabular}{|c|c|c|c|c|c|c|}
\hline \multirow{2}{*}{\multicolumn{2}{|c|}{ Model }} & \multicolumn{2}{|c|}{$\begin{array}{c}\text { Unstandardized } \\
\text { Coefficients }\end{array}$} & \multirow{2}{*}{$\begin{array}{l}\text { Standardized } \\
\text { Coefficients } \\
\text { Beta }\end{array}$} & \multirow[t]{2}{*}{$\mathrm{T}$} & \multirow[t]{2}{*}{ Sig. } \\
\hline & & B & Std. Error & & & \\
\hline \multirow{3}{*}{1} & Constant & 16137,668 & 20872,846 & & ,773 & ,483 \\
\hline & ROA & 6305,273 & 1941,289 & 1,866 & 3,248 &, 031 \\
\hline & ROE & $-5238,201$ & 1974,993 & $-1,524$ & $-2,652$ &, 057 \\
\hline
\end{tabular}

a. Dependent Variable: Stock Price

\subsubsection{Correlation Analysis}

This analysis is used to determine the relationship between two or more independent variables $(\mathrm{X} 1, \mathrm{X} 2, \ldots \mathrm{Xn})$ to the dependent variable (Y) simultaneously.

Table 6

Correlation Analysis

Model Summary ${ }^{\mathrm{b}}$

\begin{tabular}{|c|r|r|r|r|}
\hline Model & R & R Square & $\begin{array}{l}\text { Adjusted R } \\
\text { Square }\end{array}$ & $\begin{array}{l}\text { Std. Error of } \\
\text { the Estimate }\end{array}$ \\
\hline 1 &, $855^{\mathrm{a}}$ &, 731 &, 596 & 4270,124 \\
\hline
\end{tabular}

a. Predictors: (Constant), ROE, ROA

b. Dependent Variable: H.SAHAM

Judging from the above table obtained figures $\mathrm{R}$ of 0.855 . This shows that there is a very strong relationship between the ROA and ROE to the stock price.. Same with Reseach Al-khatib, Hazem B, Al-Horani, Alaa A that Return on Equity (ROE) and Return on Assets (ROA) are the most important two financial ratios, which help in predicting the financial distress.

\subsection{Determination Analysis}

Koefisien determination shown from R-square value of 0.731 . This means that $73.1 \%$ dependent variable is the share price can be explained by two independent variables, ROA and ROE. While the remaining $26.9 \%$ is explained by variables or other causes.

From the table above it can be concluded F count $>\mathrm{F}$ table (5.422> 4.324), then Ho is rejected and Ha accepted, meaning that there is influence between the ROA and ROE to the share price. So the hypothesis that the writer suggested in chapter I, that ROA and ROE affect stock prices are acceptable.

\section{CONCLUSION}

Variation return on Asset at PT Indocement Tbk. able to explain the variation on stock prices, while ROA increases, stock prices also tend to rise, Variation Return On Equity in PT Indocement Tbk. Vaariasi able to explain the stock price, which when ROE increases, the resulting share price decline. Variations ROA and ROE are jointly able to explain the variation on share prices.

\section{ACKNOWLEDGMENT}

The researchers gave suggestions relating to this study as follows:

1. Return on Assets and Return on Equity PT.Indocement Tunggal Tbk, needs to be increased again by increasing the net profit. The increase in net income can be done by increasing the value of sales of both goods and services and cost efficiency by evaluating all costs with regard to the level of optimization.

2. The price of a single stock PT.indocement Perkasa, need to pay attention to earnings per share, interest rate, given the amount of cash dividends, the amount of profit the company obtained, the level of risk and return and marketing strategies.

3. We thank participants of the research seminar at the Universitas Pendidikan Indonesia, Global Conference on Business, Management, and Entrepreneurship, August 2016 for helpful comments. 


\section{REFERENCES}

[1] Bukit, Inka Natasya Hagaina; Anggono, Ir Achmad Herlanto, MBA, The Effect of Price to Book Value (PBV), Dividend Payout Ratio (DPR), Return on Equity (ROE), Return on Asset (ROA), and Earning Per Share (EPS) Toward Stock Return of LQ 45 for the Period of 2006-2011, Review of Integrative Business and Economics Research 2.2 (2013): 22-43.

[2] Zekic, Stanislav; Mijic, Kristina; Jaksic, Dejan Milen;kovic, Ivan, "Profitabilility Gap In The Milk Production Chain : Evidence From Serbia", Author Information, Ekonomika Poljoprivrede 63.2 (2016): 485-499.

[3] Mohammed, Abba; Usman, Suleiman, "Corporate Attibutes And Share Value Of Listed Pharmacetical Firms In Nigeria”, Researchers World 7.1 (Jan 2016) 88-98.

[4] Yousef Jahmani and Mohammed Ansari, "Managerial ownership, risk, and corporate performance", International Journal of Commerce and Management, 16.2 (Summer 2006) : p86

[5] Dahlia Pinem and Bernadin Dwi, "The analysis of company performance and sales growth to the dividend policy at the company go public in Indonesia stock exchange" International Journal of Business and Commerce. 5.6 (May 2016): p105.

[6] Syamsuddin, Lukman. "Corporate Financial Management”. Jakarta: King Grafindo Persada.,2008

[7] Kiel, G. C., \& Nicholson, G. J. (2003). Board composition and corporate performance: How the Australian experience informs contrasting theories of corporate governance. Corporate Governance, 11(3), 189-205.

[8] A.F.M. Mainul Ahsan, "Can ROE be used to predict portfolio performance?", Economics, Management, and Financial Markets. 7.2 (June 2012): p132.

[9] Astrid Amanda, "The Effects of Debt To Equity Ratio, Return on Equity, Earnings Per Share and Price Earning Ratio On The Stock Market", Faculty of Administrative Science, 2010.

[10] Vasta Biqul Khoir, "Influence Earning Per Share, Return on Assets, Net Profit Margint, Debt To Asset Ratio And Long Term Debt To Equity Ratio On The Stock Market", Faculty of Administrative Sciences UB Malang 2010.

[11] Awan, Abdul Ghafoor, Bashir, Imtiaz, 'Impact Of Dividend Announcements On Share Price Of Selected Listed Companies At KSE”, Sciense International27.4, (Jul/Aug 2015) 3523-3527.

[12] Al-khatib, Hazem B, Al-Horani, Alaa A,” Predicting Financial Distr Of Public Companies Listed In Amman Stock Exchange", European Scientific Journal, Volume 8, Jul 2012.

[13] Svetlana, Bekareva; Ekaterina, Meltenisova, “Assets' Management And Share Prices For Electric Ultilities: Empirical Results For World Electric Utilities", Economic and Social Development: Book of Proceedings: 414-424. Varazdin: Varazdin Development and Entrepreneurship Agency (VADEA), Apr 24-Apr 25, 2014. 